\title{
Anatomy Of An Acquisition: The Challenges Of Selling A Privately Held Electronics Manufacturing Company
}

\author{
George Dierberger, Augsburg University, USA \\ Marc McIntosh, Augsburg University, USA \\ Lori Lohman, Augsburg University, USA \\ Phyllis Kapetanakis, Augsburg University, USA
}

\begin{abstract}
Sweeny Electronics is a family-owned S Corporation based in St. Paul, Minnesota. The company was started in 1946 by a returning army veteran, Frank Sweeney, and focused on the heating, air quality and cooling markets. The company has survived numerous recessions, market consolidations, and manufacturing challenges. The company is currently run by the third generation of the Sweeney family, George Sweeney, who is the current owner and CEO, is approaching retirement age. The board of directors has seven members: George Sweeney, his wife Jane and five members of the business community. Under the direction of the CEO, the board has determined that there is no "heir apparent" in the family or in the current management team. They have elected to hire an investment banking firm to position the company for an asset-based sale. Sweeney would like to sell the company for estate planning purposes and allow him to transition to a consulting role with the new owner.
\end{abstract}

Keywords: Mergers and Acquisitions; Family-Owned Business; Valuation Analysis; Channel Conflict; Strategy; Marketing

\section{SUGGESTED COURSES}

The case will be most appealing to undergraduate business seniors and MBA students interested in management, finance, accounting and marketing.

\section{INTRODUCTION}

weeny Electronics is a family-owned S Corporation based in St. Paul, Minnesota. The company was started in 1946 by a returning army veteran, Frank Sweeney, and focused on the heating and cooling markets. The company has survived numerous recessions, market consolidations, foreign competition, and manufacturing challenges. The company is led by the third generation of the Sweeney family. The current owner and CEO, George Sweeney, is the grandson of the founder and is approaching retirement age; however, there is not an heir apparent as the next generation of Sweeney's are not interested in managing the business.

The board of directors has seven members: George Sweeney, his wife Jane and five members of the business community. Under the direction of the CEO, the board has determined that there is no one in the family or in the current management team capable of running the company. They have elected to hire an investment banking firm to position the company for an asset-based sale. The relevant key facts:

1) The main product lines are air circulators, heaters, purifiers, humidifiers, and steam products for cleaning.

2) The company has outsourced the manufacturing of its products in China since the early 1990s.

3) The company's distinctive design and brand have helped establish itself as a higher- priced alternative to competition and private label products. 
4) George Sweeney would like to sell the company for estate planning purposes and allow him to transition to a two-year consulting role with the new owner.

The company sells $90 \%$ of the products in the USA with the remaining $10 \%$ of revenue coming from Canada. It currently employs staff for sales, marketing, operations, logistics, new product development, website and software maintenance and warehousing. The company has struggled to generate positive income in the past fiscal year for a number of reasons:

1) The organization has grown to be inefficient with its overhead costs close to $30 \%$ of sales

2) The design patents will expire in the next 3 years. The company invested the steam business at the expense of the other businesses.

3) Sales from the company's distribution channels have shifted from specialty retailers with a higher gross margin to the mass market with a lower gross margin; on-line sales have grown with a higher gross margin.

4) The government has tightened inspection criteria for the products, which has increased factory costs.

5) Logistically, there are significant sourcing issues with the Chinese factory requirements including higher minimum quantities, and higher labor costs.

Business operations, including marketing, product development, customer service, regulatory and engineering functions, are based in St. Paul. Manufacturing is based in Shenzhen, China, an ISO9000 factory. ISO 9000 is a set of international standards on quality management and quality assurance developed to help companies effectively document the quality system elements to be implemented to maintain an efficient quality system (ASQ, 2017). Warehousing and distribution of the products are based in St. Paul, Minnesota.

The company has built a portfolio of over 400 products in its five different businesses: air circulators, space heaters, air purifiers, humidifiers, and steam products for cleaning. The products have given Sweeney Electronics access to new channels of distribution and have helped to diversify its product line in order to sell to a broader customer base. For the fiscal year 2016, it has experienced a financial loss of approximately $\$ 64,000$ on sales of $\$ 29,875,000$.

However, for the fiscal year ended 2015, Sweeney Electronics delivered a financial profit of approximately $\$ 1,141,000$ on sales of $\$ 30,550,000$. Sweeney Electronics distributes its products through three main distribution channels: retail specialty stores, mass market and online accounts. The sales trend in Table 1 denotes the sales and profits for the past three years.

Table 1. Sales and Profits

\begin{tabular}{c|c|c}
\hline Year & Sales & Profits \\
\hline 2014 & $\$ 29,900,000$ & $\$ 1,225,000$ \\
\hline 2015 & $\$ 30,550,000$ & $\$ 1,141,000$ \\
\hline 2016 & $\$ 29,875,000$ & $-\$ 64,000$ \\
\hline
\end{tabular}

Currently, over \$25 million dollars in sales come from specialty and the mass market, with consumer online sales from Amazon and other .com sites totaling $\$ 5$ million. As noted in Table 2, the commercial business is spread across a diverse group of channels and major retailers including:

- Wholesale Clubs - Costco USA, Costco Canada, Sam's Club, and BJ's

- Mass Market - Wal-Mart, Target, Meijer, Fred Meyer

- Specialty Distribution - Joann, Bed Bath and Beyond (BBB), Michaels, Hobby Lobby, and Barnes and Noble

- Home Improvement - Lowes, Home Depot, Menards 
Table 2. Percentage of Sales by Major Channel

\begin{tabular}{l|c}
\hline \multicolumn{1}{c}{ Distribution Channel } & Percentage of Sales \\
\hline Wholesale Clubs & $33 \%$ \\
\hline Direct to Consumer/website & $21 \%$ \\
\hline Amazon & $14 \%$ \\
\hline Specialty Retail & $9 \%$ \\
\hline Amazon & $14 \%$ \\
\hline Book Stores & $6 \%$ \\
\hline Home Improvement & $5 \%$ \\
\hline Mass Market & $4 \%$ \\
\hline Drug Stores & $3 \%$ \\
\hline Office Supply Products & $3 \%$ \\
\hline Discount Outlet Stores & $2 \%$ \\
\hline
\end{tabular}

The product categories are listed below in Table 3 with the total sales for three years. Growth has been slow in all of the categories with the exception of steam cleaners and in the high margin, replacement filter business.

Table 3. Top Selling Stock Keeping Units (SKU's)

\begin{tabular}{l|c|c|c}
\hline \multicolumn{1}{c}{ Product Category } & $\mathbf{2 0 1 4}$ & $\mathbf{2 0 1 5}$ & $\mathbf{2 0 1 6}$ \\
\hline Air Circulators & $\$ 6.2$ & $\$ 6.1$ & $\$ 6.3$ \\
\hline Heaters & $\$ 6.8$ & $\$ 7.0$ & $\$ 6.8$ \\
\hline Air Purifiers & $\$ 5.8$ & $\$ 6.0$ & $\$ 5.7$ \\
\hline Humidifiers & $\$ 4.8$ & $\$ 4.9$ & $\$ 4.7$ \\
\hline Steam Cleaners & $\$ 2.0$ & $\$ 3.0$ & $\$ 3.1$ \\
\hline Replacement Filters & $\$ 4.8$ & $\$ 4.9$ & $\$ 5.0$ \\
\hline
\end{tabular}

There are a number of significant opportunities left in the USA and Canada for Sweeney brands. Currently, Target, Canadian Tire, London Drug, CVS, Lowes, Kohl's, Office Depot, Essendent Wholesale, SP Richards Wholesale and other office products companies sell Sweeney products. The company is also beginning to investigate expanding internationally into Chile, Japan, New Zealand, Australia, Norway, Sweden, Finland, Denmark, and Germany.

Sweeney's direct business is over \$2 million dollars in sales and includes a database of over 45,000 consumer email addresses and over 80,000 household addresses. Sweeney Electronic Products has a long-term, profitable relationship with Amazon. Approximately 15\% of Sweeney sales are direct to the consumer through the company website and .com sites such as Target.com and Costco.com. In addition, Sweeney is constantly looking for new and emerging distribution opportunities with medical centers like the Mayo Clinic, Johns Hopkins and the Medical Clinic channel.

From a philanthropic standpoint, Sweeney prides itself on its strong commitment to corporate and social responsibility. The company continues to improve manufacturing processes and has taken steps to lessen its environmental footprint and serve as a role model to its customers. Sweeney contributes and supports non-profit organizations such as local food shelfs, Habitat for Humanity, along with mission groups in Tanzania, Namibia, and Guatemala.

\section{MARKET OVERVIEW}

Sweeney Corporation is divided into five product segments: air circulators, space heaters, air purifiers, humidifiers, and steam products for cleaning. The air circulators and air purifiers are a growing opportunity and represent the two largest market segments. The air circulators products have been redesigned in the past 2 years to reflect a modern design that complements current consumer electronics, smart phones and medical products designs. The products have passed a rigorous accelerated aging process which is evidenced by the less than 5\% returns for quality issues. In terms of performance, the products meet and exceed the competition and are competitively priced.

The patented steam cleaning products are an opportunity that requires additional resources and attention. Today, steam cleaning is a $\$ 1,500,000$ business with product sold through direct channels and some high end retailers such as 
Brookstone and The Sharper Image. The products have clear evidence of their effectiveness, but the company needs additional resources to take advantage of this market opportunity. Sweeney has a $\$ 500,000$ filter replacement business that is sold primarily through their company website, Amazon, and Costco.com in the United States and Canada. The majority of the sales are direct to consumer with very little retail presence. The filter replacement products are a residual business that does not require additional time or energy and is protected by intellectual property through a design patent.

In the past 18 months, Costco has expanded its retail distribution of Sweeney air filtration and portable heating units nationwide through its Canadian locations. In the United States, Sweeney products have made significant inroads in retail placement with Staples, Joann's, Home Depot, Meijer, Fred Meyer/Kroger, Barnes and Noble, Rite Aid, and Sam's Club. They are also launching a market test with Sam's Club in November of 2016 with air filtration. The point of sale data(POS) from the retailers continues to exceed the financial hurdles required by the buyers with the exception of a slow selling season in 2016 with Costco USA. Table 4 below, shows sales for 2015 compared to 2014. Sweeney has strategically partnered with Bed Bath and Beyond (BBB) but the annual volume rebates required, and BBB's private label products have created challenging gross margin requirements. As noted in Table 4, the strong sales growth with Amazon and Costco helped drive the key accounts:

Table 4. Sales by Key Accounts

\begin{tabular}{c|c|c|c|c|c|c|c|c|c|}
\hline Account & Amazon & BBB & Costco & Joann's & Brookstone & Walgreens & Home Depot & Staples \\
\hline 2014 & $\$ 4000$ & $\$ 1977$ & $\$ 2000$ & $\$ 1000$ & $\$ 1500$ & $\$ 800$ & $\$ 700$ & $\$ 1200$ \\
\hline 2015 & $\$ 4400$ & $\$ 2200$ & $\$ 2500$ & $\$ 1200$ & $\$ 1200$ & $\$ 400$ & $\$ 500$ & $\$ 1000$ \\
\hline
\end{tabular}

\section{STRENGTH-WEAKNESS-OPPORTUNITY-THREAT (SWOT) ANALYSIS}

In the United States, there are less than a dozen key companies competing in the consumer heating and cooling industry. The major brand name competitor that most consumers would recognize are Honeywell and Dyson, with other brands such as Lasko, Tangkula, Vornado and Holmes. A strengths-weaknesses-opportunities-threats (SWOT) analysis of all the significant competitors has been completed. Strengths and weaknesses are items the company controls while opportunities and threats are items that are influenced but not controlled. The threats are described as external conditions that are a hurdle to achieving the company objectives and opportunities are external conditions that are helpful in achieving the company objectives. In Table 5, the authors discuss how Sweeney can defend against the weaknesses and threats and how it can exploit the opportunities and strengths:

Table 5. Strengths-Weaknesses-Opportunities-Threats

\begin{tabular}{|c|c|}
\hline $\begin{array}{r}\text { STRENGTHS } \\
\end{array}$ & WEAKNESSES \\
\hline $\begin{array}{ll}\text { - } & \text { Brand awareness } \\
\text { - } & \text { Mission focused } \\
\text { - } & \text { Dedicated and loyal staff } \\
\text { - } & \text { Successful relationships/experience at retail } \\
\text { - } & \text { Consumer brand awareness } \\
\text { - } & \text { Robust on-line sales }\end{array}$ & $\begin{array}{ll}\text { - } & \text { Lack of strategic plan and vision } \\
\text { - } & \text { Product focus is broad } \\
\text { - } & \text { Number of categories and SKU's } \\
\text { - } & \text { Obsolete inventory } \\
\text { - } & \text { Investment in brand development } \\
\text { - } & \text { IT and EDI systems }\end{array}$ \\
\hline $\begin{array}{c}\text { OPPORTUNITIES } \\
\end{array}$ & THREATS \\
\hline $\begin{array}{ll}\text { - } & \text { Growth in key channels } \\
\text { - } & \text { SKU rationalization } \\
\text { - } & \text { Direct to consumer sales } \\
\text { - } & \text { New product opportunities } \\
\text { - } & \text { International expansion } \\
\end{array}$ & $\begin{array}{ll}- & \text { Highly competitive market } \\
\text { - } & \text { Increased pressure on reducing costs } \\
\text { - } & \text { Private label products through Alibaba } \\
\text { - } & \text { Cost of Goods Sold (COGS) rising in China }\end{array}$ \\
\hline
\end{tabular}

The company's strengths are the company brands, product positioning, intellectual property, production sourcing in China, regulatory expertise, direct channel database and its channel strategy. The weaknesses rest in the relatively small size of the operation: logistics, distribution, IT systems, EDI and the lack of relationships with office products distribution. The opportunities for Sweeney products are significant as it continues to gain momentum with the current 
retail partners and is engaging new opportunities with Lowes, London Drug, Canadian Tire and Target. A high profit margin opportunity is growing the direct-to-consumer channel through the use of social media, and dedicated blogs. The threats consist of significantly larger competitors such as Dyson, Honeywell, and less expensive imports from China.

\section{CHANNEL STRATEGY}

Office Products - Contract / Commercial / Wholesale / Mail-order Channel (CCWM): Includes wholesalers Essendent, SP Richards; Staples Delivered, Office Depot, Independent Stationers, Quill, and buying groups. These customers sell higher priced products, typically over $\$ 100$ retail. Products are sold through catalogs and websites with a pre-negotiated set price on core contract items (printer cartridges, Post-it notes ${ }^{\circledR}$, paper, pens, file folders etc.) and non-contract items that represent less-significant volume. The Sweeney products would fall into the non-contract area. This channel offers high gross margin but requires significant back-end rebates and long lead-times.

Retail Channel: Includes Bed, Bath. And Beyond, Barnes and Noble, Meijer, Brookstone, Fred Meyer, Joann's, Costco, Sam's Club, Wal-Mart, Target, Home Depot, Walgreens, CVS, Rite Aid, and Canadian Tire. These customers use a price-lining strategy, hitting classic retail price points like $\$ 19.95, \$ 29.95$, etc. The retail channel tends to be seasonal with higher inventory levels stocked before school, winter and special events.

Direct Channel: Includes Amazon (seller central, higher volume inventory stocked by Amazon) and vendor central (slower moving inventory drop-shipped to the consumer by Sweeney), Amazon Canada, Costco.com, Sweeney catalog and web sales. They sell the full range of products with no limitations on price point.

Government: Federal government sales to Base Supply Stores and GSA (possibly through National Institute of the Blind/National Institute of the Severely Handicapped).

International: Canada, Europe, Australia, Japan

\section{SALES MANAGEMENT}

The sales force for Sweeney consists of a national sales manager two sales assistants and independent sales representatives who are paid a 5\% commission. The Sweeney sales team has been spread thin due to expansion into new channels of distribution and creating internal house accounts with Staples, Target, Joann's, Sharper Image, and Brookstone.

\section{PRODUCT CATEGORIES}

The Sweeney brand is the market leader in mid - to high - level circulators and fans. This strong market share translates into strong Sweeney brand awareness with consumers who recognize the unique design and quality performance. The consumer target market demographic for Sweeney are females between the ages of 25-65, who are college educated, with high disposable income.

Sweeney's retail placement is quite extensive covering multiple channels of distribution. Further market penetration continues to be an opportunity with unit growth projected to grow at the market rate of 3-5\% on an annual basis (World, 2017) over the next five years. A significant opportunity exists to increase category awareness and increase unit sales through leveraging the Sweeney brand and utilizing a direct sales force with the office products retail channel (Staples, Quill, Office Depot, Essendent, S.P. Richards). However, Sweeney's infrastructure, distribution system and information technology support needs updating and improvements. Sweeney Corporation drop-ships orders for Staples, Quill and others, but they have struggled to deliver products within the promised 24-hour period, resulting in fines for late processing and billing.

In Sweeney's discussions with Staples and Office Depot it became it quickly became apparent that there is a significant opportunity in the Office Products Channel. According to Kaiser, there are approximately 65 million white collar 
workers in the USA (Kaiser, 2015). A large number of white-collar workers are situated in offices that may require additional heating or cooling equipment.

On the retail side, in October 2014, Sweeney rolled out nationwide programs with Staples Office Products and Office Depot for heaters and fans. The results were mediocre given the poor foot traffic into the office product stores and competition from online retailers. However, on the commercial side of the business, the HVAC market grew $4.9 \%$ at a compound annual growth rate from 2011-2016. The total market size for commercial offices exceeds $\$ 88$ billion and serves over 105,000 customers in the United States (World, 2017). On the contract side, Sweeney is seeing a significant increase in drop- ship orders for products to corporate, commercial accounts and schools. Sweeney is at the embryonic stage of introducing fans and coolers in the commercial office market with its first exposure to the channel in 2014. There is still untapped market potential in the office products retail channel with over 21,000 storefront locations. However, high inventory turnover expectations are unlikely to happen because of the proliferation of on-line sales and the declining retail foot traffic.

In terms of competition, Dyson and Honeywell present the largest branded challenge. In addition, private label products from Bed Bath and Beyond (BBB) and other retailers continues to grow at a rapid rate. The branded competitors do not have a comprehensive, integrated marketing plan that includes the following: social media, catalog and internet sales, key account penetration and public relations. Based on a review of the competitive websites, it does not appear that any of the other competitors utilize catalogs for customers in the manner that the Sweeney brand utilizes them for consumer marketing; they only offer online shopping in an eCatalog format or use of the site's search function (Students to complete competitive analysis; Exhibit B).

\section{Circular Fans}

Sweeney cooling fans have been retooled and positioned for significant growth with the majority of sales coming from newly designed products that are less than three years old. This is a seasonal product line with growth potential. The strategic initiative includes the next generation of circular fans. The fans will be designed with Bluetooth compatibllity for smart phones using a mobile app to help differentiate the product line from competition. The ISO9000 factory in China is responsible for the quality, regulatory adherence and consistency of the circular fan product line adhering to specifications written by the Sweeney research and development team in the United States.

In summary, circular fans represent a growth opportunity for Sweeney but will also require continued research and development dollars for the next generation of circular fans (Students to complete competitive analysis in Exhibit B).

\section{Heaters}

Space heaters are a core business for Sweeney, with stiff competition from China and private label brands. The majority of the space heater products use similar technology and have turned into commodity items with competition from Holmes, Honeywell, and Lasko. These competitors also sell directly to consumers using their internet sites as well as on Amazon. An analysis of the competition reveals the following:

- Lasko Metal Products was founded in 1906 by Henry Lasko in Philadelphia. Lasko has developed their product line by listening to customers and their changing needs. The growth in population after World War II, moved Lasko into small appliances, fans and portable heaters for home and businesses. The company experienced strong growth and expanded manufacturing operations to Tennessee and Texas where production continues today (Lasko, 2016). The company has grown into an international organization and market leader in portable fans and ceramic heaters including room fans, high velocity fans, ceramic, and low-profile heaters.

- Holmes small electronics is owned by Sunbeam and Jarden companies. Holmes Products Corporation, or Holmes Group is based in Milford, Massachusetts. According to the website, Holmes produces mechanical fans, air heaters, and humidifiers. Holmes Products was founded by Jordan Kahn in 1982 (Holmes, 2016). In 2005, Berkshire Partners, Holmes' parent company, sold Holmes Products to Jarden Corporation for $\$ 625.9$ million USD. At the time of the sale, the Holmes brand family included Rival (acquired in 1999), Crock-Pot, Bionaire and White Mountain (Holmes, 2016). 
- Honeywell is a leading brand known for its quality and range of consumer products for the home, including heating devises (Honeywell, 2016). They are a powerful brand across several businesses and are a formidable competitor.

Sweeney products continue to be updated based on market research and analyzing trends in the market. Recent market research findings indicated a desire by consumers to have an interactive app to help with heating and cooling needs (World I. , 2017). Sweeney's ability to stay close to the consumer and listen to the needs of the marketplace is critical for future product development.

A market analysis of the channels conducted by Sweeny in 2014 focused on the number of retail stores by channel of distribution. There are over 30,000 store location opportunities in the USA with specialty retail, mass and club markets, office products, and home improvement channels. This does not include industrial distribution opportunities with Fastenal, Grainger and other accounts.

In summary, heating products, are relatively new to the office products retail channel. Staples began carrying this category business began in 2014 and should reach $\$ 400,000$ in sales in 2017. There is a significant opportunity for heater sales within the commercial office products channel (Students to complete the competitive intelligence table, Exhibit B) (Bizjournal, 2015).

\section{Air Purifier Products}

The Sweeney Air Purifier products is a mature product line with a significant number of competitors such as Honeywell, Alen, Oransi, and Vornado. Sweeney products hold a slight intellectual property advantage with several design patents. Alen, based in Austin Texas, only sell air purifiers and is one of the stronger competitors. The company has an experienced management team and has HEPA approved air purifiers (Alen, 2016). Oransi is also based in Austin Texas and all of its products are made in the USA. It also focuses on only air purifiers (Oransi, 2017).

Honeywell is an international company and has been in the air purification industry for over 40 years. The products offer a high efficiency particulate air (HEPA) for general air cleaning with $99.97 \%$ capture rate at 3 microns (Honeywell, 2016). Honeywell products tend to be more expensive and are harder to find at retail. The company makes the following claims for its products:

1. Captures up to $95-99 \%$ of airborne particles, at two microns or larger, from the air that passes through the filters.

2. Mechanical filtration with optional on-off ionization (particles are forced through and trapped in a filter).

3. Filters typically need to be replaced once every 4-6 months.

4. Optional odor absorbing pre-filter.

In summary, the products represent a strong office products distribution opportunity given growing concerns about employee health and the spread of germs during the winter flu season, especially relative to lost productivity and absenteeism. There is a year-round need for this product line given the poor air quality in many offices and homes (Students to complete the competitive intelligence table, Exhibit B).

\section{Humidifiers}

The Global Humidifiers Market 2015-2019 - industry analysis report states consumers are increasingly becoming aware and conscious about health related issues in the home, at work and the impact on their health and quality of living. This could lead to increased sales in humidifiers (Bizjournal, 2015). The analysts forecast global humidifier sales of over $\$ 850$ million dollars market and is expected to grow at a CAGR of 5.2\% from 2016-2023 (Insights, 2015). According to the Global Humidifiers report, humidifiers are devices that aid in regulating humidity levels in enclosed spaces and are extensively used in the industrial, commercial, and residential segments (Insights, 2015). 
The global market for humidifiers is expected to surpass $\$ 1$ billion in sales by 2019 as a result of consumer awareness regarding air quality (Insights, 2015). There are three product-based segments in this market (Insights, 2015):

- Warm-mist humidifiers

- Ultrasonic humidifiers

- Cool-mist humidifiers

Market research analysts have estimated the warm-mist humidifiers segment to account for more than $40 \%$ of the total market share by 2019 (Insights, 2015). New product innovations by manufacturers and the increasing move to application based smart phone technology will help manufacturers gain a competitive advantage in the market. The key competitors in the market are Honeywell, Boneco, Jarden and Vicks. Boneco is a Swiss based company started in 1956. They are owned by Plaston and have their primary market in Europe. Total sales are $\$ 40$ million dollars and are sold primarily in Europe and the United States (Boneco, 2018). Vicks is primarily an over the counter medication company owned by Helen of Troy. Its primary brand is Nyquil ${ }^{\circledR}$ and is the market leader in its category. Vicks was purchased by Proctor and Gamble in 1985 (Vicks, 2017). The sales in the category is small, less than $\$ 10$ million dollars but uses Vicks lotions in the humidifiers to help with breathing (Vicks, 2017).

Humidity can be a significant problem in homes located in the United States. According to research, if there is low humidity that cause dryness problems while over 50\% humidity encourages dust mites and encourage mold spore growth (HVAC, 2018). The level of indoor humidity that can be modified by mechanical means is dependent on outdoor humidity. All humidifiers have some level of sound when the water in the tanks is drawn into the base of the units, and the noise can be bothersome to consumers who are sensitive to loud sounds. Cool mist humidifiers will cover a larger area, but since they are noisier, consumers normally place them in an isolated part of the home or office.

Consumers can purchase hygrometers for testing which will provide a rough estimate of humidity. All humidifiers have some maintenance costs associated with them, typically between $\$ 30$ to $\$ 50$ for annual filter and other replacement costs (Honeywell, 2016).

In summary, the humidifier products are a solid contributor to the sales and profits for the company but will require additional investments to stay current with competition (Students to complete the competitive intelligence table, Exhibit B).

\section{Steam Cleaning}

According to IBIS World, the carpet cleaning industry revenue is expected to increase at a rate of the gross domestic product (GDP). As the economy in the United States continues to improve, rising per capita disposable income should have a positive impact on the steam cleaning industry in the consumer and commercial sectors. Consumers' with disposable income tend to spend money on carpet cleaning services (World, 2017).

According to IBIS World, the cleaning industry can be roughly divided into residential cleaning, commercial janitorial services, specialty cleaning and laundry/dry cleaning services. In 2015 there were approximately 875,000 businesses employing over 3.5 million people (World, 2017).

The steam cleaning industry as a whole is susceptible to economic downturns and suffered through several rough years during the great recession, as revenue fell 5.3\% in 2008 and another $6.1 \%$ in 2009 (World, 2017). As such, general cleaning services, and particularly residential services, are considered by consumers to be an expendable luxury. As a result of the years of economic recovery, the cleaning industry has bounced back, and in 2015 it generated $\$ 51$ billion in revenue (World, 2017). This positive business trend can be attributed to low unemployment and low office vacancy rates. In summary, the steam cleaning business is extremely competitive, and Sweeney has been late to the market with its product line (Students to complete the competitive intelligence table, Exhibit B). 


\section{Human Resources}

Sweeney Corporation currently has 45 people on its payroll; including the senior management team of George Sweeney (CEO), Herb Holman (CFO), Cory Erickson (Manufacturing), Will Ponner (Sales and Marketing), John Stark (New Product Development), Paul Mullaney (Legal and Regulatory). The majority of its employees are located in Minnesota (42) with three located at the factory in China. In Figure 1, note the organizational chart of each person and function. The following people are considered critical to assure the successful transition from Sweeney Corporation to the acquiring company.

Figure 1. Organization Chart

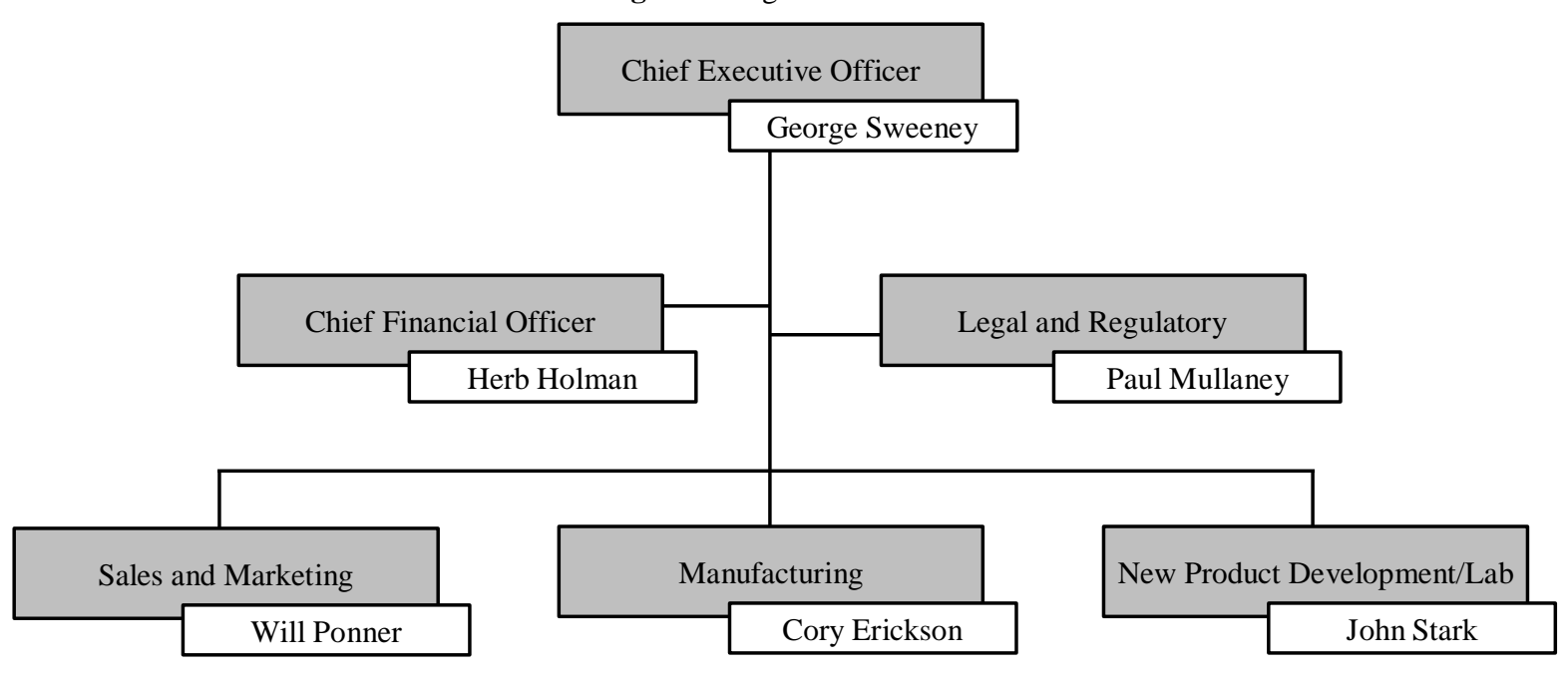

Herb Holman - St. Paul - Chief Financial Officer. Herb has been the CFO for a number of start-up companies. He is an experienced CPA and has been with Sweeney for the past 6 years.

Will Ponner- St. Paul - Marketing Director. Paul has been a part of several large organizations in his career including Medtronic and Pella. He has worked diligently on building the Sweeney brand and has completed a number of strong marketing campaigns using social media and search engine optimation (SEO).

Paul Mullaney- St. Paul - Legal and regulatory. Paul has been with Sweeney for five years and has moved from a local law firm to handle the company's legal and regulatory compliance issues.

John Stark - New Product Development. John is a retired St. Jude Medical mechanical engineer and has been busy renovating the product portfolio with updated technology and innovative products. His experience with international business has been very helpful with commercializing the new products and working closely with the plant in China.

Cory Erickson - China - Manufacturing. Cory has been based in China for the past 5 years. He has worked for Medtronic, St. Jude Medical and Stratmarc medical manufacturing. Cory works closely with John Stark in the laboratory to manufacture the products according to the highest standards.

\section{FINANCIAL ANALYSIS}

A company's return on invested capital (ROIC) is defined as the after tax operating profit divided by invested capital in fixed assets plus working capital. The long-term revenue growth will be the two most important drivers of shareholder returns particularly for companies that have high returns on capital (Koller, 2015). Closely correlated with long term revenue growth will be an assessment of Sweeney's ability to find new product markets with high profit growth potential. Furthermore, long term value cannot be created without satisfied customer, suppliers and employees. 
Acquirers will be accessing whether Sweeney has a well-defined competitive advantage which can sustain strong growth in the future. In all likely less focus will be placed on the company's management team and more so on the Company's competitive advantage as espoused by Kaplan and Norton (Kaplan, 2008) in their horse versus jockey analogy, where it is far better to have a sustainable competitive strategy than a strong management team which in theory is more easily replaceable (Koller, 2015).

In Table 6, a summary of Michael Porter's classic Competitive Strategy (Porter, 1998) should provide some useful guidelines on how acquirers will access Sweeney's competitive position: the threat of new entry, pressure from substitute products, the bargaining power of buyers, the bargaining power of suppliers and the intensity of rivalry among current competitors (Koller, 2015) further expounds upon the sources of competitive advantage as follows:

Table 6. Porters Competitive Strategy

\begin{tabular}{l|l}
\hline \multicolumn{1}{c}{ Price Premium } \\
$\begin{array}{l}\text { Innovative products: Difficult to copy or patented products, } \\
\text { services of technologies }\end{array}$ & $\begin{array}{l}\text { Innovative business method: Difficult to copy business } \\
\text { method that contrasts with established industry practice }\end{array}$ \\
\hline $\begin{array}{l}\text { Quality: Customers willing to pay a premium for a real or } \\
\text { perceived difference in quality over and above competing } \\
\text { products or services }\end{array}$ & $\begin{array}{l}\text { Unique resources: Advantage resulting from inherent } \\
\text { geological characteristics or unique access to raw materials }\end{array}$ \\
\hline $\begin{array}{l}\text { Brand: Customers willing to pay a premium based on brand, } \\
\text { even if there is no clear quality difference }\end{array}$ & $\begin{array}{l}\text { Economies of scale: Efficient scale or size of the relevant } \\
\text { market }\end{array}$ \\
\hline $\begin{array}{l}\text { Customer lock-in: Customers unwilling or unable to replace } \\
\text { product or service they use with a competing product or } \\
\text { service }\end{array}$ & $\begin{array}{l}\text { Scalable product/process: Ability to add customers and } \\
\text { capacity at negligible marginal cost }\end{array}$ \\
\hline $\begin{array}{l}\text { Rational price discipline: Lower bound on prices } \\
\text { established by large industry leaders through price signaling } \\
\text { or capacity management }\end{array}$ & \\
\hline Porter, 1998) &
\end{tabular}

Sweeney should be prepared to address various metrics that will be analyzed during the due diligence process by potential acquirers including short term value drivers surrounding productivity of its sales (market share, pricing strategy) force, operations (component costs analysis) and its capital (working capital and equipment and its longer term value drivers surrounding product pipeline, brand strength, customer satisfaction, ability to manage its costs will be assessed as well (Koller, 2015).

Subsequently, acquirers will most likely attempt to translate these qualitative factors into a revenue forecast using either a top-down forecast in which revenues are estimated by sizing the total market, estimating prices and determining market share or alternatively using a bottom-up approach where extensive due diligence is performed on the company's own forecasts of demand from existing and new potential customers given industry dynamics, historical evidence of growth, and competitive positioning (Koller, 2015).

In the final analysis acquirers will be determining how various problems associated with Sweeney's low ROIC can be fixed. For instance, can cost reductions be implemented, can revenue growth be accelerated? Is there be better utilization of fixed and working capital (Koller, 2015)?

The more Sweeney can demonstrate strength in value driver performance the higher the price they will achieve (Koller, 2015). In Figure 2, provides an excellent roadmap for optimizing value for a typical manufacturing company. 
Figure 2. Koller's Valuation

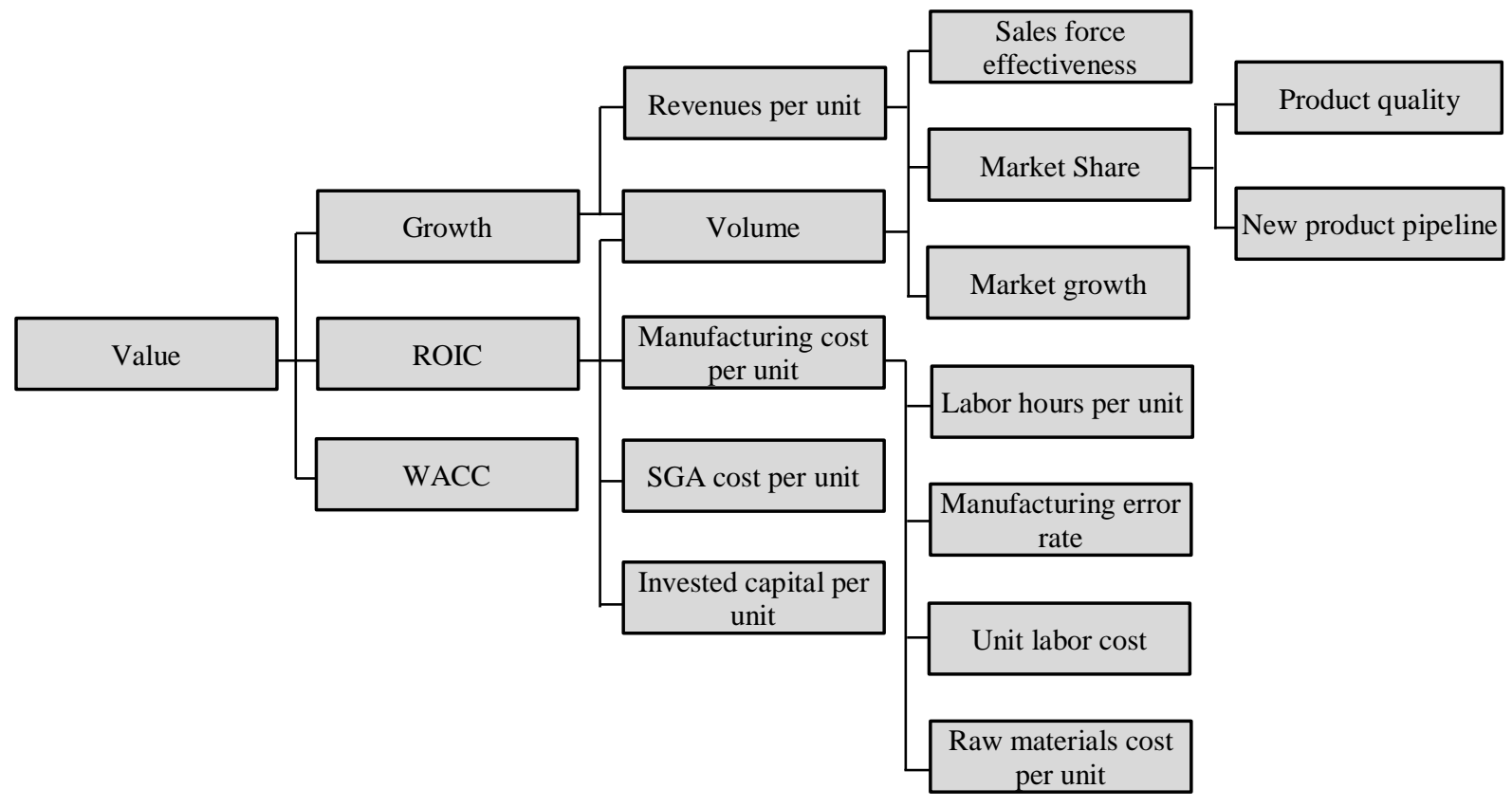

From a theoretical perspective, when valuing a company, two approaches are traditionally used: Discounted Cash Flow (DCF) approach and the Multiples approach to valuation. Due to its relative high accuracy and flexibility The DCF approach is recognized as the most popular framework used by practitioners and academic since it is based on actual cash flows of the company rather than accounting-based earnings (Koller, 2015). It discounts free cash flow (available to all capital providers- equity investors, lenders, and other non-equity investors) by the weighted average cost of capital or blended cost of capital for capital providers. Recognizes that potential acquirers will only create value if the returns on invested capital that is used to purchase a company exceeds their cost of capital. Stated another way by Burr in his 1938 treatise, The Theory of Investment Value" "the value of the investment is the cash it will pay out to the owner over the life of the investment, discounted to a rate that reflects current market conditions and the risk of the investment" (Burr, 1938). The discount rate of the DCF method should in essence reflect the uncertainty surrounding the generation of future cash flows. In other words, the greater the risk, the less someone will be willing to pay for Sweeney as the lower purchase price is used to provide a greater return for the acquirer (Trugman, 2002).

The Multiples approach is a relatively simpler way to value companies by valuing companies in relation to the value of similar companies in a similar industry. Care must be taken though in insuring that comparable companies have similar performance as measure by ROIC and growth, no small task when accessing the relative valuation of Sweeney, a small privately held electronics company. Koller articulates that "selecting the right peer group is critical to coming up with a reasonable valuation using multiples. Common practice is to select a group of 8 to 15 peer organizations and take the average of the multiples of the peer group. Getting a reasonable valuation, though, requires judgement about which companies and their multiples are truly relevant for the valuation" If valid, comparable companies can be found, earnings or cash flow multiples (a common cash flow multiple would be enterprise value divided by earnings before interest, taxes, depreciation and amortization), can provide critical insights and secondary support for testing and summarizing a valuation analysis and determining what drives value in a given industry but should not be used as a shortcut to one's valuation analysis (Koller, 2015).

Finally, it is important to note that the "final" value reached for Sweeney may be above (premium) or below (discount) the theoretical value calculated by either of these methods. Since Sweeney is a unique, closely held, private company, a controlling interest is said to be worth more than a minority interest; a discount may be warranted since access to reliable data may be problematic for closely held small companies which means higher risk for the acquiring company; and finally, a "key person discount" is frequently seen in the valuation of a closely held business (Koller, 2015). 


\section{CONCLUSION}

The case provides students with an opportunity to improve gross margins by strategically addressing the following areas: 1) additional sales through the direct channel and Amazon; 2) High profit retail accounts; and 3) sales to the office products channel. As noted in Table 7, the commercial gross margin has decreased by $2 \%$ in 2016 . Sweeney should strategically determine which items were being sold at a low gross margin and stop or reduce selling to those respective accounts. Greater emphasis should be placed on selling items that are profitable. One example would to reduce the amount sold to Bed, Bath and Beyond (BBB) in order to decrease operational costs and increase gross margin.

Table 7. Gross Margin Analysis

\begin{tabular}{l|c|c|c}
\hline \multicolumn{1}{c}{ Gross Margin \% } & F2016 & Budget & \multicolumn{2}{c}{ Variance } \\
\hline Retail & $39 \%$ & $41 \%$ & $-2 \%$ \\
\hline Direct & $60.3 \%$ & $65 \%$ & $-5 \%$ \\
\hline Total & $43 \%$ & $47 \%$ & $-4 \%$ \\
\hline
\end{tabular}

The direct channel is the highest gross margin business at $60 \%$. Sweeney needs to develop additional products to specifically sell in this channel. Expansion into additional heating products will help create awareness for the need for other products in the home and office markets. Sweeney currently has a database of over 40,000 email addresses and 80,000 mailing addresses and it needs new products to help drive sales and increase profits.

The club business currently is the lowest gross margin commercial business for Sweeney. The landed factory cost is $\$ 32$ for the majority of the heating SKU's and the sell price to Costco is $\$ 44$. However, there are opportunities to improve manufacturing processes and efficiencies to reduce the factory cost percentage and enhance profitability. There are additional opportunities with the club channel in new product areas such as humidifiers which could generate $\$ 1.5$ million in profitable sales. Expansion into other core product areas for home improvement will generate $\$ 1.5$ million in sales within Costco USA alone. One critical issue would be to have Costco take possession of the goods once it clears customs in the USA in order to receive payment earlier and avoid inventorying the product in the Sweeney Warehouse facility.

The office products channel presents a significant opportunity for Sweeney products to increase gross margin and sales. The contract/commercial/wholesale channels do not have the same financial pressure as retail. Exposure in the catalogs should contribute an additional $\$ 3$ million plus in sales in 2018. Expanding into this channel is one of the top priorities for 2017. Staples Corporation has renewed its contract for two years for the delivered and .com businesses. Office Depot/Office Max present a significant opportunity for sales in their catalog and direct business. In summary, Sweeney's brand is well positioned to grow profitably with diverse distribution across multiple channels. The direct channel is a profitable segment that is rich with consumer data which will help identify new product opportunities.

\section{STUDENT INSTRUCTIONS AND KEY DELIVERABLES}

Using the information provided in this case, students are to assume the role of consultants hired by the board of directors to perform analysis and provide constructive recommendations for the future. The following deliverables in Table 8 should be prepared for presentation. 
Table 8. Student Instructions

\begin{tabular}{|c|c|}
\hline Deliverable & Learning Objective \\
\hline $\begin{array}{l}\text { Report: Prepare a detailed report to the board of directors } \\
\text { with your recommendations for selling the company. This } \\
\text { report should be based on the items you prepare for question } \\
\text { 2. Include a detailed explanation of how you would position } \\
\text { the company for sale. The recommendations must include a } \\
\text { rationale for the valuation of the company. }\end{array}$ & $\begin{array}{l}\text { 1. Demonstrate an understanding of the process and } \\
\text { operational challenges of the electronics equipment } \\
\text { industry } \\
\text { 2. Demonstrate a methodology for understanding the } \\
\text { channel strategy by benchmarking competition in each } \\
\text { product category }\end{array}$ \\
\hline $\begin{array}{l}\text { Financial statement modeling and analysis: Prepare a } \\
\text { professional Excel based model to include but not be limited } \\
\text { to the following: } \\
\text { 1) Horizontal, vertical and margin analysis of the } \\
\text { statement of operations for past three years. Include } \\
\text { analysis of the gross margin by distribution channel. } \\
\text { 2) Inventory assessment including analysis and } \\
\text { rationalization of the number of SKUs along with } \\
\text { specific recommendations for expansion and } \\
\text { contraction. Analysis of distribution channels along } \\
\text { with a recommendation for which ones the } \\
\text { organization should utilize going forward. Your } \\
\text { position must be supported with data analysis. } \\
\text { 3) Breakeven analysis for the company by channel of } \\
\text { distribution. } \\
\text { 4) Complete the competitive analysis in Exhibit B for } \\
\text { each product category }\end{array}$ & $\begin{array}{l}\text { 3. Ability to perform financial analysis of the channels of } \\
\text { distribution. This includes horizontal, vertical and ratio } \\
\text { calculations and analysis, and breakeven analysis by } \\
\text { business channel. } \\
\text { 4. Perform an inventory analysis and recommend the } \\
\text { stock keeping units (SKUs) to be offered in units and } \\
\text { dollars for the retail market } \\
\text { 5. Competitive review by major stock keeping unit and } \\
\text { price points }\end{array}$ \\
\hline $\begin{array}{l}\text { Presentation Items: } \\
\text { 1. Professional Power Point summarizing the key } \\
\text { recommendations } \\
\text { 2. Executive Summary - a one page, bullet point } \\
\text { synopsis of the key findings and recommendations } \\
\text { (Instructor note): For online courses these items could be } \\
\text { placed in a shared file location, and delivered via an online } \\
\text { forum such as Skype or Google Hangout. }\end{array}$ & $\begin{array}{l}\text { 6. Draw meaningful conclusions and make professional } \\
\text { recommendations and presentations. }\end{array}$ \\
\hline
\end{tabular}

\section{INSTRUCTOR NOTES AND RECOMMENDATIONS}

In completing this case, students will need to demonstrate the following learning outcomes:

1) Demonstrate an understanding of the operational challenges managing a family owned business

2) Demonstrate an understanding of Sweeney's channel strategies by determining the best way for it to maximize valuation for purposes of selling the company either partially or in its entirety.

3) Demonstrate the ability to perform a valuation analysis and recommend a price for the business.

4) Complete a competitive analysis of the major competitors by channel, stock keeping unit and price point.

5) Demonstrate an understanding of the financial status of the five businesses. This includes horizontal and vertical margin calculations and business channel gross margin analysis.

6) Draw meaningful conclusions and make final recommendations to the board of directors.

The recommendations and salient points we recommend in this case study include distribution, SKU rationalization, operational challenges, channel strategy, current financial assessment and a pro-forma income statement with the recommended changes. A successful implementation of the strategies identified will provide an opportunity for Sweeney to move into position to sell to investors at a high multiple of EBITDA.

There are a number of recommendations based on various aspects of the case. 


\section{Distribution}

- Concentration on the company's core mission by expanding the office products, and its more profitable channels.

- Phase out of the low margin businesses because of strong competition and lack of product differentiation

- Increase direct sales by $15 \%$, enabling Sweeney to improve overall gross margins

- Create products specifically for the direct channel that are feature rich and not contingent on retail price points

\section{Finance and Inventory}

Inventory reduction of product SKU's:

- $\quad$ SKU Reduction Plan

Improves gross margin

- Focus on most profitable items

- Remaining SKU's have a combined gross margin of only $22.89 \%$

- Improves cash flow through reduced inventory

- Reduce the total number of product SKU's to the top 30\% based on the sales-to-profit ratio

Marketing:

- Explore licensing options which could be valued at $10 \%$ of the annual sales.

- Social media and search engine optimization (SEO)

- Research current customer trends

- Continue focus on sharing success stories

- Share upcoming events through different social media venues (ex: Facebook, Twitter, and Instagram)

- Conduct further research on competition

Operations:

- Maintain outsourcing operations until the business is stabilized.

- Once the business is profitable then management should explore manufacturing and packaging the product at their own facility 
EXHIBIT A: Statement of Operations

\begin{tabular}{|c|c|c|c|}
\hline Revenue & FY 20X4 & FY20X5 & FY20X6 \\
\hline \multicolumn{4}{|l|}{ Retail- BBB, Joann's etc. } \\
\hline 40110 Air Circulators & $\$ 4,000$ & $\$ 4,040$ & $\$ 4,121$ \\
\hline 40310 Heaters & 3,500 & 3,623 & 3,767 \\
\hline 40130 Purifiers & 3,000 & 3,060 & 3,060 \\
\hline 40320 Humidifiers & 2,000 & 2,050 & 2,112 \\
\hline 40350 Steam Cleaners & 1,000 & 1,020 & 1,056 \\
\hline Total Chain Sales & $\$ 13,500$ & $\$ 13,793$ & $\$ 14,115$ \\
\hline \multicolumn{4}{|c|}{ On-line to consumer - Amazon, company store } \\
\hline 40110 Air Circulators & 2,000 & 2,060 & 2,142 \\
\hline 40310 Heaters & 1,500 & 1,583 & 1,677 \\
\hline 40130 Purifiers & 1,000 & 1,020 & 1,046 \\
\hline 40320 Humidifiers & 500 & 515 & 538 \\
\hline 40350 Steam Cleaners & 500 & 510 & 528 \\
\hline Total Sales & $\$ 5,500$ & $\$ 5,688$ & $\$ 931$ \\
\hline \multicolumn{4}{|l|}{ Club and Mart Sales } \\
\hline 40110 Air circulators & 4,000 & 4,080 & 4,019 \\
\hline 40310 Heaters & 3,500 & 3,450 & 3,400 \\
\hline 40320 Humidifiers & 3,000 & 3,045 & 3,091 \\
\hline \multicolumn{4}{|l|}{40390 Total Retail and Discounts } \\
\hline Total Retail Sales & $\$ 10,615$ & $\$ 10,696$ & $\$ 10,859$ \\
\hline Total Net Revenue & $\$ 29,615$ & $\$ 30,176$ & $\$ 30,906$ \\
\hline \multicolumn{4}{|l|}{ Cost of Goods Sold } \\
\hline \multicolumn{4}{|l|}{ COGS -Retail } \\
\hline 50110 Air Circulators & 2,600 & 2,704 & 2,812 \\
\hline 50310 Heaters & 3,000 & 3,180 & 3,323 \\
\hline 50130 Purifiers & 1,800 & 1,890 & 2,003 \\
\hline 50320 Humidifiers & 1,200 & 1,236 & 1,285 \\
\hline 50350 Steam Cleaners & 600 & 606 & 618 \\
\hline Total COGS - Bulk (Corporate ) & $\$ 9,200$ & $\$ 9,616$ & $\$ 10,042$ \\
\hline \multicolumn{4}{|l|}{ COGS -on-line to consumer } \\
\hline 50110 Air Circulators & 1,300 & 1,352 & 1,406 \\
\hline 50310 Heaters & 1,286 & 1,363 & 1,424 \\
\hline 50130 Purifiers & 600 & 630 & 668 \\
\hline 50320 Humidifiers & 300 & 309 & 321 \\
\hline 50350 Steam Cleaners & 300 & 303 & 309 \\
\hline Total COGS - Bulk (Religious) & $\$ 3,786$ & $\$ 3,957$ & $\$ 4,128$ \\
\hline \multicolumn{4}{|l|}{ COGS - Clubs and Marts } \\
\hline 50330 Air Circulators & 2,600 & 2,808 & 3,005 \\
\hline 50120 Heaters & 2,000 & 2,080 & 2,163 \\
\hline 50600 Humidifiers & 1,800 & 1,863 & 1,947 \\
\hline Total COGS - Retail & 6,400 & 6,751 & 7,115 \\
\hline Total COGS & $\$ 19,386$ & $\$ 20,324$ & $\$ 21,285$ \\
\hline Gross Profit & $\$ 10,229$ & $\$ 9,852$ & $\$ 9,621$ \\
\hline \multicolumn{4}{|l|}{ Operating Expenses } \\
\hline Total SG\&A Expenses & 9,000 & 9,100 & 9,700 \\
\hline Net Profits & $\$ 1,229$ & $\$ 752$ & $\$(79)$ \\
\hline Donations & 100 & 100 & \\
\hline Net Income or Loss & $\$ 1,129$ & $\$ 652$ & $\$(79)$ \\
\hline
\end{tabular}


EXHIBIT B: Competitive Analysis

Circular Fans

\begin{tabular}{|c|c|c|c|}
\hline \multirow{2}{*}{\multicolumn{4}{|c|}{$\begin{array}{l}\text { Brand } \\
\text { Honeywell }\end{array}$}} \\
\hline & & & \\
\hline Dyson & & & \\
\hline $\mathrm{BBB}$ private label & & & \\
\hline
\end{tabular}

Circulators

\begin{tabular}{|c|c|c|c|}
\hline Brand & Number of SKU's & Value Proposition & Price Points \\
\hline Honeywell & & & \\
\hline Dyson & & & \\
\hline BBB private label & & & \\
\hline
\end{tabular}

\section{Heaters}

\begin{tabular}{|l|l|l|l|}
\hline \multicolumn{1}{|c|}{ Brand } & Number of SKU's & Value Proposition & Price Points \\
\hline Honeywell & & \\
\hline Dyson & & & \\
\hline BBB private label & & \\
\hline
\end{tabular}

Air Purifiers

\begin{tabular}{l|l|l|l}
\hline \multicolumn{1}{|c|}{ Company } & Number of Products & Value Proposition & Price Points \\
\hline Honeywell & & & \\
\hline Oransi & & & \\
\hline Alen & & \\
\hline
\end{tabular}

\section{Humidifiers}

\begin{tabular}{|c|c|c|c|}
\hline Brand & Number of SKU's & Value Proposition & Price Points \\
\hline Honeywell & & & \\
\hline Dyson & & & \\
\hline $\mathrm{BBB}$ private label & & & \\
\hline Sweeney & & & \\
\hline
\end{tabular}

\section{Steam Cleaners}

\begin{tabular}{|c|c|c|c|}
\hline Brand & Number of SKU's & Value Proposition & Price Points \\
\hline Honeywell & & & \\
\hline Dyson & & & \\
\hline BBB private label & & & \\
\hline
\end{tabular}




\title{
TEACHING NOTES
}

\section{Anatomy of an Acquisition: The Challenges of Selling a Privately Held Electronics Manufacturing Company}

\author{
George Dierberger, Augsburg University \\ Marc McIntosh, Augsburg University \\ Lori Lohman, Augsburg University \\ Phyllis Kapetanakis, Augsburg University
}

This case was prepared by the authors and is intended to be used by undergraduate seniors and MBA students in preparation for a career in management, marketing or finance. The views represented here are those of the authors and do not necessarily reflect the views of the journal. The views are based on the professional judgment of the authors and their experiences with positioning an organization for sale. Copyright $@ 2017$ by the authors. No part of this work may be reproduced or used in any form or by any means without the written permission of the authors.

\section{CASE OVERVIEW}

Sweeny Electronics is a family-owned S Corporation based in St. Paul, Minnesota. The company was started in 1946 by a returning army veteran, Frank Sweeney, and focused on the heating and cooling markets. The company has survived several challenges including: recessions, market consolidations, competition, and manufacturing challenges. The company is currently run by the third generation of the Sweeney family. The current owner and CEO, George Sweeney, is the grandson of the founder and is approaching retirement age without an heir apparent as his children are not interested in managing the business.

The board of directors has seven members: George Sweeney, his wife Jane and five members of the business community. Under the direction of the CEO, the board has determined that there is no one in the family or in the current management team capable of running the company. They have elected to hire an investment banking firm to position the company for an asset-based sale. The relevant key facts:

- The main product lines are air circulators, heaters, purifiers, humidifiers, and steam products for cleaning.

- The company has outsourced the manufacturing of its products in China since the early 1990s.

- The company's distinctive design and brand have helped establish itself as a higher- priced alternative to competition and private label products.

- George Sweeney would like to sell the company for estate planning purposes and allow him to transition to a two-year consulting role with the new owner.

The company sells $90 \%$ of the products in the USA with the remaining $10 \%$ of revenue coming from Canada. It currently employs staff for sales, marketing, operations, logistics, new product development, website and software maintenance and warehousing. The company has struggled to generate positive income in the past year for a number of reasons:

- The organization has grown to be inefficient with its overhead costs close to $30 \%$ of sales

- The design patents will expire in the next 3 years. The company invested in the steam business at the expense of the other businesses.

- Sales from the company's distribution channels have shifted from specialty retailers with a higher gross margin to the mass market with a lower gross margin; on-line sales have grown with a respectable gross margin.

- The government has tightened inspection criteria for the products, which has increased factory costs.

- Logistically, there are significant sourcing issues with the Chinese factory requirements including higher minimum quantities, and higher labor costs. 
The case is most appropriate for undergraduate business seniors and MBA students interested in mergers and acquisitions, family-owned businesses, finance, multiple-channel strategy, and management.

\section{RESEARCH METHODS}

The name of the company has been disguised. The information regarding the product groups and the size of the respective markets have been verified through industry resources and public information.

\section{LEARNING OUTCOMES}

In completing this case, students should be able to:

- Demonstrate an understanding of the operational challenges managing a family owned business

- Demonstrate an understanding of Sweeney's channel strategies by determining the best way for it to maximize valuation for purposes of selling the company either partially or in its entirety.

- Demonstrate the ability to perform a valuation analysis and recommend a price for the business.

- Complete a competitive analysis of the major competitors by channel, stock keeping unit and price point.

- Demonstrate an understanding of the financial status of the five businesses. This includes horizontal and vertical margin calculations and business channel gross margin analysis.

- Draw meaningful conclusions and make final recommendations to the board of directors.

\section{DISCUSSION QUESTIONS}

1) What would you include in a detailed report to the investors with your recommendations for selling the company?

2) How you would you position the company for sale and who would you recommend as a possible acquiring company?

3) What is the gross margin for each channel of distribution (mass, specialty, club and direct channels)?

4) Moving forward, what channels of distribution would you continue to invest in and what channels would you rationalize?

5) Would you recommend a multiple off of EBITDA or base your acquisition price on discounted cash flow? Compare and contrast the two methods.

Instructor Note: For online courses, competitive information could be placed in a shared file location and delivered via an online forum such as Skype or Google Hangout.

\section{ANSWERS TO DISCUSSION QUESTIONS}

1) What would you include in a detailed report to investors with your recommendations for selling the company?

The investors will be looking for a financial history of the past three years for the Sweeney business which is included in the case. The students will need to take the information given and project sales and profits for the next 3-5 years. Where is the growth going to come from and how will an acquiring company expand the business? The acquiring company will need to see continuing positive cash flow for the next five years in order to pay a multiple for the business.

The students should also include a market basket analysis by each product group. The analysis should include the total market size for North America and market share by major competitor by each category. The students should be required to develop a SWOT analysis for each major competitor. 
2) How you would you position the company for sale and who would you recommend as a possible acquiring company?

The company needs to be positioned as a growth opportunity in at least 3 of the major product categories by an organization participating in one of the categories looking to expand into new categories. The students should create adjusted financial scenarios using pro-forma profit and loss statements for the investors that includes a data based path for increased profits and sales. There are several clues in the case that speaks to high operating costs. The information in the case offers the students the opportunity to reduce overhead operating costs by streamlining the organization. An adjusted EBITDA that includes a projected lower SG\&A would increase the multiple for an acquisition. This method suggests that an organization who is a competitor in one of the categories would be an excellent candidate to purchase Sweeny's businesses and treat the acquisition as an adjacent market opportunity.

3) What is the gross margin for each channel of distribution (mass, specialty, club and direct channel) and what recommendations would you make regarding the product lines?

The gross margin for each channel is listed in the case study. The students need to apply common sense to the answer. The easy answer would be to cut the lowest cost gross margin distribution channels. The more nuanced answer is to establish the market size by each product group, then analyze the strength of each competitor by reviewing the growth trends in each specific industry. A review of the competitors, their market share, distribution, unique value propositions and patent positions are critical components required to successfully answer the questions in the case. Once the market size and opportunity have been established an adjusted EBITDA can be established with the assumptions listed.

4) Moving forward, what channels of distribution would you continue to invest in and what distribution channels would you rationalize?

The students should examine the current market share by product group in each of the major channels. A more in-depth answer would be the market share enjoyed by Sweeney, the market potential for each channel and where the growth will be coming from in the next 5 years. The students should collect the data for each of the major competitors, by channel and product group. By establishing the leaders by product group, the market trend for the growth of the product category the data would suggest the markets that Sweeney should be investing in and where the future growth will be coming from in order to entice an acquiring company to purchase the company.

5) Would you recommend a multiple off of EBITDA or base your acquisition price on discounted cash flow? Compare and contrast the two methods.

We would recommend the students utilize both methods in order to create a range for the potential valuation of the company. The EBITDA method is used by many investment banking companies to establish a range for the purchase of the company. The students should also look at other acquisitions in the same type of industry to establish the "norm" for the recommended multiple for EBITDA.

Due to its relative high accuracy and flexibility The discounted cash flow (DCF) approach is used by practitioners since it is based on actual cash flows of the company rather than accounting-based earnings (Koller, 2015). It discounts free cash flow by the weighted average cost of capital or blended cost of capital for capital providers. DCF recognizes that potential acquirers will only create value if the returns on invested capital that is used to purchase a company exceeds their cost of capital. The discount rate of the DCF method should in essence reflect the uncertainty surrounding the generation of future cash flows. In other words, the greater the risk, the less someone will be willing to pay for Sweeney as the lower purchase price is used to provide a greater return for the acquirer (Trugman, 2002). In the final analysis, the acquiring company will offer to purchase Sweeny at a price that will be a ROIC for their organization. 


\section{AUTHOR BIOGRAPHIES}

Dr. George Dierberger is an Assistant Professor at Augsburg University, Minneapolis, Minnesota. His teaching areas of expertise include innovation and design, leadership, organizational development, change management, international business and strategic management. Research interests primarily focus on the scholarship of entrepreneurship, innovation, and leadership. Dr. Dierberger spent 25 years in a variety of leadership positions at $3 \mathrm{M}$ and continues to consult for entrepreneurial organizations.

Dr. Lori Lohman is an Associate Professor of Marketing and Associate Chair of the Business Administration Department at Augsburg University. She has over 30 years of collegiate teaching experience in the marketing and management fields and has won two teaching awards. Prior to entering academia, she worked in the newspaper, consumer finance, marketing research and toy industries. She is particularly interested in the use of faculty members as interns within businesses as a way to benefit both parties, as well as students. She holds a PhD, MBA and BA from the University of Minnesota.

Dr. Marc McIntosh is an Assistant Professor of Finance in the Business Administration Department of Augsburg University. He has worked as a Senior Investment Banker and Corporate Finance Executive with over 20 years of corporate and international project finance experience having successfully executed multi- million dollar transactions for both domestic and international companies. Dr. McIntosh received his Doctorate in International Business in February, 2007 from Argosy University and his Masters in Business Administration from Harvard University in 1981. In addition, he is a registered Certified Public Accountant.

Phyllis Kapetanakis is an assistant professor at Augsburg University, Minneapolis, Minnesota. Her teaching areas of expertise include accounting and finance. Research interests primarily focus on the scholarship of teaching and learning.

\section{REFERENCES}

Alen. (2016, December 17). https://www.alencorp.com/aboutus. Retrieved from www.alencorp.com/: https://www.alencorp.com/ ASQ. (2017, October 19). ASQ.com. Retrieved from ASQ: http://asq.org/learn-about-quality/iso-9000/overview/overview.html Bizjournal. (2015, September 28). http://www.bizjournals.com. Retrieved from bizjournals.com: http://www.bizjournals.com/prnewswire/press_releases/2015/09/28/MN13129

Boneco. (2018, April 30). Boneco healthy air. Retrieved from www.boneco.us.com: https://www.boneco.us/enus/product/product-info/humidifiers/

Burr, J. (1938). The theory of investment value. Boston: Harvard University Press.

Holmes. (2016, December 11). Homes.com. Retrieved from https://www.holmesproducts.com/info-center: https://www.holmesproducts.com/info-center/product-support-education-center.html

Honeywell. (2016, December 16). https://www.honeywellpluggedin.com/air-purifiers. Retrieved from www.honeywellpluggedin.com/air-purifiers/how-do-technologies-differ: https://www.honeywellpluggedin.com/airpurifiers/how-do-technologies-differ

HVAC. (2018, March 21). hvac. Retrieved from www.hvac.com: https://www.hvac.com/faq/recommended-humidity-level-home/

Insights, G. M. (2015, July 19). Global Market Insights.com. Retrieved from Global Market Insights: https://www.gminsights.com/industry-analysis/air-humidifier-market

Kaiser, H. (2015, May 29). Henry Kaiser Family Foundation State Health Facts. Retrieved from Henry J. Kaiser Family Foundation : http://kff.org/other/state-indicator/blue-and-white-collarworkers/?dataView=1\&currentTimeframe=0\&sortModel=\%7B $\% 22$ colId $\% 22: \% 22$ Location $\% 22, \% 22$ sort $\% 22: \% 22$ asc $\% 22 \% 7 \mathrm{D}$

Kaplan, R. N. (2008). The execution premium: Linking strategy to operations for competitive advantage. Boston: Harvard Business School.

Koller, T. G. (2015). Valuation measuring and managing the value of companies. Hoboken: John Wiley and Sons.

Lasko (2016, November 19). laskoproducts about-us. Retrieved from http://www.laskoproducts.com: http://www.laskoproducts.com/about-us/

Oransi (2017, January 2). www.oransi.com/air-purifiers-s/111.htm?gclid=CLub0eyqsdECFUm1wAod6gYGiA. Retrieved from www.oransi.com: http://www.oransi.com/air-purifiers-s/111.htm?gclid=CLub0eyqsdECFUm1wAod6gYGiA

Porter, M. (1998). Competitive strategy techniques for analyzing industries and competitors. Boston : Free Press.

Trugman, G. (2002). Understanding business valuation: A practical guide to valuing small to medium-sized businesses. Jersey City: Ner Jersey American Institute of Certified Public Accountants. 
Vicks (2017, September 15th). wikipedia. Retrieved from wikipedia: https://en.wikipedia.org/wiki/Vicks

World, I. (2017, January 17th). IBIS world. Retrieved from IBIS World.com: https://www.ibisworld.com/industry-trends/marketresearch-reports/administration-business-support-waste-management-services/administrative/carpet-cleaning.html

World, I. (2017, January 18). IBIS World .com. Retrieved from IBIS World: Where Knowledge if Power:

https://www.ibisworld.com/industry/default.aspx?indid=1945 
NOTES 